\title{
Cytotoxic and immunotoxic effects of the mixture containing cyanotoxins on carp cells following in vitro exposure
}

\author{
ANNA RYMUSZKA, ANNA SIEROSEAWSKA
}

Department of Physiology and Ecotoxicology, Institute of Biotechnology, The John Paul II Catholic University of Lublin, Lublin, Poland

\begin{abstract}
Additive, synergistic or antagonistic effects of various types of cyanotoxins have so far not been investigated. The aim of this study was to assess the potential synergistic effects of microcystin-LR and anatoxin-a on immune cells isolated from the common carp (Cyprinus carpio L.). Cytotoxicity of the toxin mixture to leukocytes, its influence on lymphocyte proliferation, as well as phagocytosis and intracellular production of reactive oxygen species by phagocytes were assessed. The membrane integrity in leukocytes decreased significantly only at the highest concentration used of the toxins in the mixture. The toxins caused oxidative stress in fish leukocytes by increasing the generation of reactive oxygen species. Moreover, the suppressive effects of toxins on the essential immune cell functions: lymphocyte proliferation and phagocytosis were observed. These results clearly demonstrate that the toxins have an immunotoxic influence on the different parameters of carp immune cells.
\end{abstract}

Key words: microcystin-LR, anatoxin-a, common carp, immunotoxicity.

(Centr Eur J Immunol 2013; 38 (2): 159-163)

\section{Introduction}

Cyanobacteria are photosynthetic prokaryotes, which are among the oldest organisms on Earth, known to produce a broad spectrum of secondary metabolites with potential pharmacological applications, for example as anti-fungal, anti-viral, antimicrobial, or antitumor agents [1,2]. Most species of cyanobacteria are capable of producing toxins, called cyanotoxins, which have health implications for both humans and aquatic organisms. Cyanotoxins, depending on their toxic activity, are divided into hepatotoxins (microcystins, nodularin), cytotoxins (cylindrospermopsin), neurotoxins (anatoxin-a, saxitoxin) and dermatotoxins (lyngbyatoxin A, aplysiatoxins and endotoxin - LPS) [3].

Most reported incidents of poisoning by cyanotoxins were associated with hepatotoxic and neurotoxic blooms of cyanobacteria. Exposure to cyanotoxins such as microcystins (MCs) and anatoxin-a (ATX-a) has led to the death of terrestrial and aquatic animals and also humans [4]. These toxins have different chemical structures, MCs are polycyclopeptides, while ATX-a is an alkaloid. These dif- ferent chemical properties may complicate the simultaneous detection of their toxicity $[3,5]$.

The health risk caused by cyanotoxin exposure is difficult to quantify since some cyanobacteria species are capable of producing 3-4 types of toxins as well as different toxin congeners (e.g. microcystin congeners). Interestingly, sometimes different cyanobacterial species may occur together at the same place and time [6]. Previously, cytotoxic and immunotoxic effects of selected cyanotoxins have been examined in many studies [7-11], but information on the toxicity of cyanotoxin mixtures is limited. The objective of the present study was to evaluate in vitro immunotoxic potential of the mixture containing two cyanotoxins, MC-LR and ANTX-a, in pure forms.

\section{Material and methods \\ Toxins}

The following cyanotoxins in pure form were used in this study: microcystin-LR (MC-LR; $\mathrm{C}_{49} \mathrm{H}_{74} \mathrm{~N}_{10} \mathrm{O}_{12}$ ), purchased from Alexis Biochemicals (Switzerland) and ATX-a in the

Correspondence: Dr Anna Rymuszka, Department of Physiology and Ecotoxicology, Institute of Biotechnology, The John Paul II Catholic University of Lublin, 14 Al. Racławickie Street, 20-950 Lublin, Poland, e-mail: anrym@kul.lublin.pl 
form of ( \pm )-anatoxin-a fumarate $\left(\mathrm{C}_{10} \mathrm{H}_{15} \mathrm{NO} . \mathrm{C}_{4} \mathrm{H}_{4} \mathrm{O}_{4}\right)$ purchased from Tocris Bioscience (UK). Pure MC-LR (1 mg) was dissolved in $1 \mathrm{ml}$ of dimethylsulphoxide (DMSO, POCh, Poland). ATX-a was dissolved in phosphate buffered saline (PBS, Biomed, Poland) to get a basic solution with a concentration of $1 \mathrm{mg} / \mathrm{ml}$. The tested concentrations $(0.01,0.1$, 0.5 and $1 \mu \mathrm{g} / \mathrm{ml}$ ) of toxins in the mixture ( $1: 1$ ratio) were prepared in the culture medium - RPMI 1640 medium (Biomed, Poland).

\section{Animals}

All work with animals was conducted in accordance with the Local Committee of Ethics on animal experimentation guidelines (approval number 9/2009). Common carp, (Cyprinus carpio L.; mean weight: $200 \mathrm{~g}$ ), were obtained from a local commercial farm. The fish were firstly acclimatized in an aerated freshwater tank at $20^{\circ} \mathrm{C}$, with a $12 \mathrm{~h}$ light/12 $\mathrm{h}$ dark period and were fed with commercial pellet food for 7 days prior to their use in the study.

\section{Cell isolation}

Before obtaining materials for the cell isolation, fish $(n=5)$ were anaesthetised with $0.2 \%$ Propiscin (Źabieniec, Poland) diluted in water. The head kidney immune cells (lymphocytes and phagocytes) were isolated using a previously described technique [12]. Briefly, the organs were passed through a nylon mesh $(100 \mu \mathrm{m})$ with RPMI 1640 medium containing $1 \%$ streptomycin/penicillin solution (Sigma, Aldrich), $10 \%$ of carp serum and $20 \mathrm{U} / \mathrm{ml}$ of heparin (Sigma, Aldrich). The cell suspensions were placed onto a discontinuous gradient of Percoll (1.02, 1.06, 1.07 and $1.08 \mathrm{~g} / \mathrm{ml}$, Sigma, Aldrich) to obtain fractions enriched in different leukocyte subsets and centrifuged at $400 \times \mathrm{g}$ for $30 \mathrm{~min}$ at $4^{\circ} \mathrm{C}$. After centrifugation, the cells were recovered, washed twice and resuspended in RPMI 1640 medium. Viable lymphocytes and phagocytic cells including neutrophils (about 10\%) and macrophages (about 90\%) were counted using a Nucleo Counter YC-100 (Chemometec) according to the manufacturer's procedure.

\section{Cytotoxicity assays}

Cytotoxic action of the toxins on leukocytes was determined by using CellTiter - Glo ${ }^{\circledR}$ Luminescent Cell Viability Assay (Promega, Madison, WI), based on quantification of intracellular ATP indicating the presence of metabolically active cells. According to the producer's protocol, leukocytes $\left(1 \times 10^{6}\right.$ per wells) were placed in 96 -well plates and exposed to the mixture containing two pure cyanotoxins: MC-LR and ATX-a (at a ratio of $1: 1$ ), at different concentrations $(0.01,0.1,0.5$ and $1 \mu \mathrm{g} / \mathrm{ml})$ at room temperature for 24 hours. Afterwards, the lyophilized reagent containing luciferin and luciferase was added to each well. The contents were mixed for 2 min to induce cell lysis and left for $10 \mathrm{~min}$ to stabilize the luminescence signal. The luminescence was measured using a luminometer (FLUOstar Optima, BMG Labortechnik).

Cell viability was determined by using the CytoToxOne $^{\mathrm{TM}}$ Homogeneous Membrane Integrity Assay (Promega, USA) that measures the release of lactate dehydrogenase (LDH) from cells with a damaged membrane. In brief, leukocytes were placed in 96-well plates and incubated with and without (control) different concentrations of the toxins for $24 \mathrm{~h}$ at room temperature. According to the protocol of the kit, the LDH activity was measured in culture supernatants and in the remaining cells after their lysis. The fluorescence was determined with an excitation wavelength $560 \mathrm{~nm}$ and an emission wavelength $590 \mathrm{~nm}$, using a fluorometer (FLUOstar Optima, BMG Labortechnik). Maximum LDH release (positive control) was induced by the cell treatment with $0.2 \%$ Triton $\mathrm{X}-100$.

\section{Lymphocyte proliferation}

Cells $\left(1 \times 10^{6}\right.$ cells $\left./ \mathrm{ml}\right)$ were seeded onto 96 -well plate and incubated with or without stimulator, mitogen concanavalin A at $50 \mu \mathrm{g} / \mathrm{ml}$ (ConA, Sigma Aldrich). Subsequently, the mixture of the toxins was added to the cells and incubated for further $24 \mathrm{~h}$. Cell proliferation was assayed by the bromodeoxyuridine (BrdU) cell proliferation assay kit (Cell Proliferation ELISA, BrdU, Roch Applied Science) in accordance with the manufacturer's instructions. BrdU was added to the cells to label newly synthesized DNA. After $24 \mathrm{~h}$ incubation with BrdU, the cells were fixed and denatured, and incubated with anti-BrdU antibody. Incorporated BrdU was measured using a luminescence reader. Stimulation Index (SI) was determined by comparing mitogen stimulated cells to unstimulated (mitogen-free) cells.

\section{Respiratory burst activity}

The phagocytic cells $\left(5 \times 10^{6}\right.$ cells $\left./ \mathrm{ml}\right)$ were transferred into 96-well plates and exposed to the mixture containing two pure cyanotoxins, MC-LR and ANTX-a (at a ratio of $1: 1)$, at different final concentrations $(0.01,0.1,0.5$ and $1 \mu \mathrm{g} / \mathrm{ml}$ ) for $24 \mathrm{~h}$ at room temperature. Then, toxins were removed and cells were mixed with $0.1 \%$ nitroblue tetrazolium (NBT, POCH, Lublin, Poland) solution containing $1 \mu \mathrm{g} / \mathrm{ml}$ of PMA (Phorbol 12-Myristate 13-Acetate; Sigma, Aldrich). After incubation for $60 \mathrm{~min}$, cells were centrifuged at $500 \mathrm{~g}$ for $3 \mathrm{~min}$, and the supernatant was removed. The reaction was stopped by adding $100 \%$ methanol. The formed formazan crystals were solubilised in $120 \mu \mathrm{l} /$ well of $2 \mathrm{M}$ potassium hydroxide ( $\mathrm{KOH}, \mathrm{POCH}$, Lublin, Poland) and $140 \mu \mathrm{l} /$ well of DMSO. The optical density of the solution was measured at $620 \mathrm{~nm}$ using a microplate reader.

\section{Phagocytic activity}

Phagocytotic activity of fish leukocytes was measured with Vybrant Phagocytosis Assay Kit (Molecular Probes, Eugene, OR) according to the manufacturer's instructions. 
Briefly, cells $\left(1 \times 10^{6}\right.$ cells $\left./ \mathrm{ml}\right)$ were seeded to 96 -well plate and incubated for $24 \mathrm{~h}$ at different concentrations of the mixture $(0.01,0.1,0.05,1 \mu \mathrm{g} / \mathrm{ml})$, followed by $2 \mathrm{~h}$ incubation with the fluorescein-labelled Escherichia coli. After the phagocytotic reaction, the cells were treated with Trypan blue for $1 \mathrm{~min}$. The results were read in a fluorescence plate reader using $\mathrm{Ex}=480 \mathrm{~nm}$ and $\mathrm{Em}=520 \mathrm{~nm}$ wavelengths. Results are expressed as a percentage of phagocytosis relative to untreated cells.

\section{Statistical analysis}

All data were shown as mean \pm SD. Statistical analysis was performed by the analysis of variance (ANOVA) using the Statistica 9 (StatSoft, Tulsa, OK, USA) software package. When differences were identified between groups, a multiple comparison Duncan's test was conducted. Differences were considered significant when $P<0.05$.

\section{Results}

\section{Cytotoxicity determination}

The in vitro cytotoxic effects of the mixture (MC-LR and ATX-a) were assessed using two methods: measurements of the cellular ATP content and the cell membrane integrity (Fig. 1).

The study revealed that the mixture of the toxins at concentrations from 0.01 to $1 \mu \mathrm{g} / \mathrm{ml}$ did not reduce the intracellular ATP level in leukocytes in comparison to the toxin-free control.
Plasma membrane integrity was assessed by monitoring LDH leakage into the extracellular medium. Only at the highest concentration of the toxins, a significant $(P<0.05)$ release of LDH from leukocytes was recorded.

\section{Lymphocyte proliferation}

Changes of the lymphocyte proliferation response to different concentrations of the mixture (MC-LR and ATX-a) are shown in Fig. 2. The concentrations of toxins from 0.01 to $1 \mu \mathrm{g} / \mathrm{ml}$ significantly decreased lymphocyte proliferation $(P<0.05)$. The maximum effect was observed at $1 \mu \mathrm{g} / \mathrm{ml}$ of the toxins. The proliferative ability of the toxin-treated cells was lowered to $50 \%$ of the control cell proliferative activity.

\section{Respiratory burst activity}

Production of the ROS in carp leukocyte cells treated with the toxin mixture increased significantly compared to cells without the toxins (Fig. 3). Incubation with 0.1 and $1 \mu \mathrm{g} / \mathrm{ml}$ of the toxins significantly increased ROS production although the highest level of stimulation was seen in leukocytes treated with $0.05 \mu \mathrm{g} / \mathrm{ml}$ of the mixture.

\section{Phagocytic activity}

The mixture of MC-LR and ATX-a inhibited phagocytosis in carp leukocytes. Incubation with $0.1,0.5$ and $1 \mu \mathrm{g} / \mathrm{ml}$ of the toxins resulted in a significant decrease in phagocytic activity of the fluorescein-labelled E. coli compared to the control cells without toxins. Incubation of cells

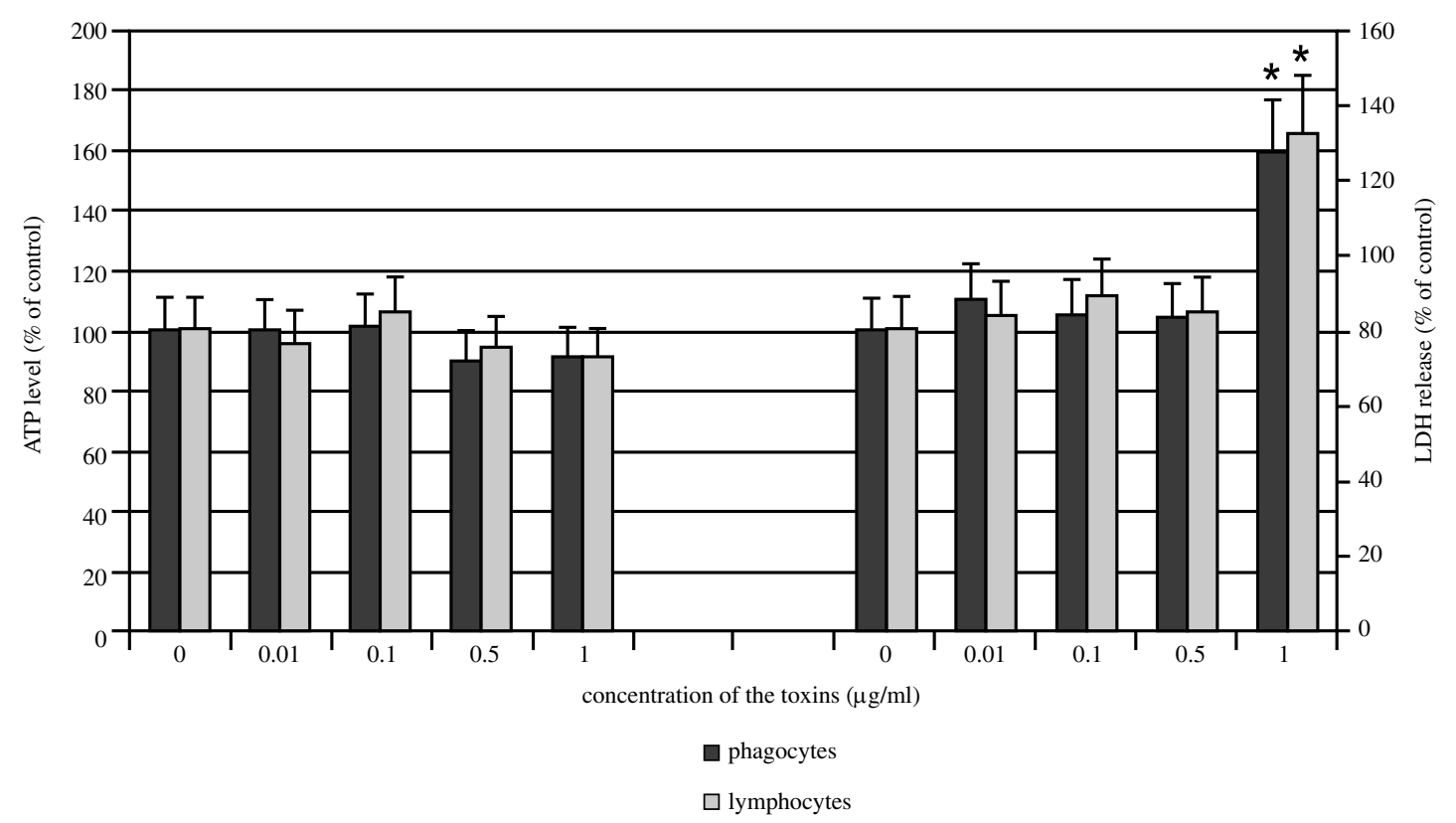

Fig. 1. Cytotoxicity of the mixture containing MC-LR and ATX-a on leukocytes isolated from carp head kidney. Cytotoxic effects were measured by ATP and LDH assay. Percent changes in ATP levels and LDH release in fish phagocytes and lymphocytes. Results are expressed as mean $\pm \mathrm{SD}$. Asterisks indicate results significantly different from the control $(P<0.05)$ 


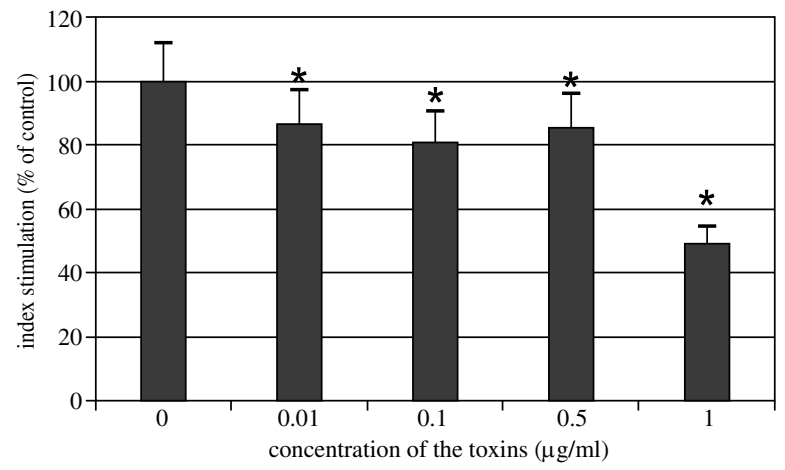

Fig. 2. In vitro effects of the mixture containing MC-LR and ATX-a on the proliferative ability of carp lymphocytes stimulated by ConA. Results are expressed as a Stimulation Index. Data are shown as mean $\pm \mathrm{SD}, n=10$. Asterisks indicate results significantly different from the control $(P<0.05)$

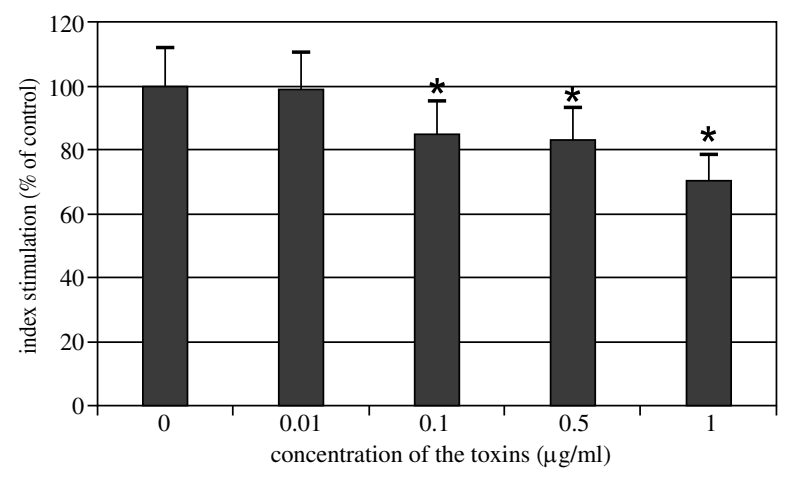

Fig. 4. In vitro effects of the mixture containing MC-LR and ATX-a on phagocytosis of carp leukocytes. Quantitative phagocytosis assay was performed in the presence or absence of 0.01 , $0.1,0.5$ and $1 \mu \mathrm{g} / \mathrm{ml}$ toxins. Data are shown as mean $\pm \mathrm{SD}$, $n=10$. Asterisks indicate results significantly different from the control $(P<0.05)$

with $0.01 \mu \mathrm{g} / \mathrm{ml}$ of the mixture had no effect on this innate immunological parameter (Fig. 4).

\section{Discussion}

Our understanding of the mechanisms underlying the immune effects of cyanotoxins is still incomplete and insufficient. It is essential to understand the hazard and risk of a single toxin but also the hazard and risk connected with the exposure to the toxin mixtures. The present in vitro study showed that the toxin mixture (MC-LR and ATX-a) at used concentrations did not reduce cellular ATP levels. On the other hand, the LDH release in carp leukocytes was increased after the incubation of cells with the highest concentration of the toxin mixture, indicating that the mixture caused directly damage the cell membrane (Fig. 1). In con-

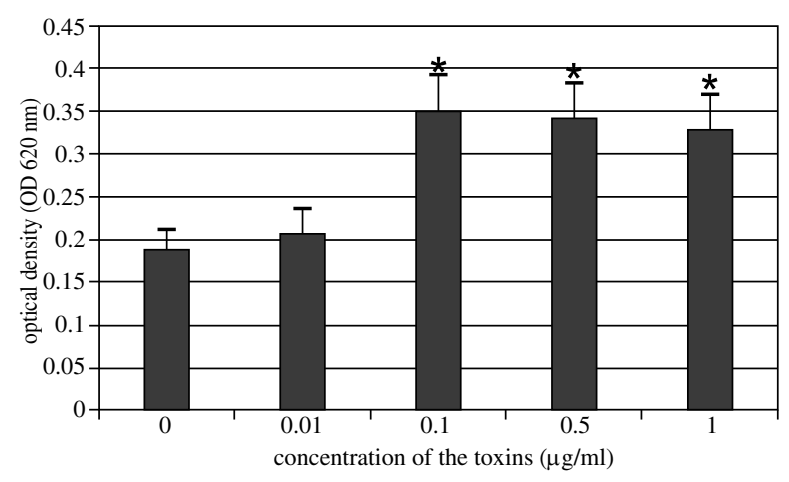

Fig. 3. In vitro influence of the mixture containing MC-LR and ATX-a on the respiratory burst activity of carp phagocytes stimulated with PMA. Data are shown as mean $\pm \mathrm{SD}, n=10$. Asterisks indicate results significantly different from the control $(P<0.05)$

trast, our earlier studies found that viability and membrane integrity in leukocytes decreased significantly after exposure to the pure MC-LR at various concentrations (from 0.01 to $1 \mu \mathrm{g} / \mathrm{ml}$ ) [13]. Several toxicological studies have indicated that neurotoxin, ATX-a has low toxicity as it is less stable. Microcystins are highly stable and are known to cause the disruption of numerous physiological mechanisms [6].

The present study demonstrated that MC-LR with ATX-a alter the basic functions of fish leukocytes, such as the proliferation of lymphocytes, the metabolic activity of the phagocytes and phagocytosis. ROS produced by activated phagocytic cells are necessary for phagocytosis and have important roles in cell signalling [14]. Changes in the studied cell functions could be attributed to the direct action of toxins on the redox state of the cells. The results demonstrated that the toxin mixture caused oxidative stress in fish leukocytes by increasing the generation of ROS (Fig. 3). Interestingly, the combined exposure to MC-LR and ATX-a amplifies the inhibition of lymphocyte and phagocyte activity. A significant and concentration-dependent decrease in lymphocyte proliferation was observed after application of the mixture at all used toxin concentrations (Fig. 2). Similar results for phagocytosis were obtained (Fig. 4). Comparing the results of the present study with the results of previous studies, we can conclude that the lymphocyte proliferation and phagocytosis in cells incubated with the toxin mixture were more significantly decreased than those in MC-LR or ATX-a treatment alone [10, 11, 13, 15]. The results suggest the synergistic effect of these various types of cyanotoxins. Unfortunately, information about the potential synergistic effect of cyanotoxins is limited. Rogers $e t$ al. [16] concluded that the synergistic effect of MC-LR and ATX-a was due to the different routes toxin uptake. The results of our previous in vitro and in vivo investigations also showed that the extract containing MCs or ATX-a 
induced greater suppressive effects on essential functions of immune cells (ROS production, lymphocyte proliferation and cytokine production) than the pure toxins alone $[10-13,15]$. Probably, the extract contained other unknown toxic metabolites produced by cyanobacteria which were responsible for the observed toxicity [17]. Moreover, Majsterek et al. [18] reported that the extract containing MCs inhibited the activity of mitochondrial oxidase to a much higher extent than the same concentration of the purified MC-LR standard.

In conclusion, this study demonstrated synergistic effects among various cyanobacterial metabolites such as MC-LR and ATX-a.

The authors declare no conflict of interest.

This research was supported by the National Center for Science, Grant No. N N304 306940.

\section{References}

1. Skulberg OM (2000): Microalgae as a source of bioactive molecules - experience from cyanophyte research. J Appl Phycol 12: 341-348.

2. Rastogi RP, Sinha RP (2009): Biotechnological and industrial significance of cyanobacterial secondary metabolites. Biotechnol Adv 27: 521-539.

3. van Apeldoorn ME, van Egmond HP, Speijers GJ, Bakker GJ (2007): Toxins of cyanobacteria. Mol Nutr Food Res 51: 7-60.

4. Codd GA, Morrison LF, Metcalf JS (2005): Cyanobacterial toxins: risk management for health protection. Toxicol Appl Pharmacol 203: 264-272.

5. Funari E, Testai E (2008): Human health risk assessment related to cyanotoxins exposure. Crit Rev Toxicol 38: 97-125.

6. Ibelings BW, Chorus I (2007): Accumulation of cyanobacterial toxins in freshwater "seafood" and its consequences for public health: a review. Environ Pollut 150: 177-192.

7. Sierosławska A, Rymuszka A, Bownik A, Skowroński T (2007): The influence of microcystin-LR on fish phagocytic cells. Hum Exp Toxicol 26: 603-607.

8. Zhang H, Zhang J, Chen Y, Zhu Y (2008): Microcystin-RR induces apoptosis in fish lymphocytes by generating reactive oxygen species and causing mitochondrial damage. Fish Physiol Biochem 34: 307-312.

9. Li Y, Sun B, Wu H, et al. (2009): Effects of pure microcystinLR on the transcription of immune related genes and heat shock proteins in larval stage of zebrafish (Danio rerio). Aquaculture 289: 154-160.

10. Rymuszka A, Sieroslawska A (2011): Effects of neurotoxin anatoxin-a on common carp (Cyprinus carpio L.) innate immune cells in vitro. Neuroendocrinol Lett 32: 84-88.

11. Rymuszka A (2012): The cytotoxic activity of the neurotoxin anatoxin-a on fish leukocytes-in vitro and in vivo. Acta Vet Brno 81: 175-182.

12. Rymuszka A, Adaszek Ł (2012): Pro- and anti-inflammatory cytokine expression in carp blood and head kidney leukocytes exposed to cyanotoxin stress - an in vitro study. Fish Shellfish Immunol 33: 382-388.

13. Rymuszka A (2012): Microcystin-LR induces cytotoxicity and affects carp immune cells by impairment of their phagocyto- sis and the organization of the cytoskeleton. J Appl Toxicol DOI 10.1002/jat.2791.

14. Tort L (2011): Stress and immune modulation in fish. Dev Comp Immunol 35: 1366-1375.

15. Rymuszka A, Sierosławska A, Bownik A, Skowroński T (2010): Microcystin-LR modulates selected immune parameters and induces necrosis/apoptosis of carp leucocytes. Environ Toxicol Chem 29: 569-574.

16. Rogers EH, Hunter ES 3rd, Moser VC, et al. (2005): Potential developmental toxicity of anatoxin-a, a cyanobacterial toxin. J Appl Toxicol 25: 527-534.

17. Nováková K, Babica P, Adamovský O, Bláha L (2011): Modulation of gap-junctional intercellular communication by a series of cyanobacterial samples from nature and laboratory cultures. Toxicon 58: 76-84.

18. Majsterek I, Sicinska P, Tarczynska M, et al. (2004): Toxicity of microcystin from cyanobacteria growing in a source of drinking water. Comp Biochem Physiol C 139: 175-179. 